\section{Shelf life evaluation of ricotta fresca sheep cheese in modified atmosphere packaging}

\author{
Carlo Pala, ${ }^{1}$ Christian Scarano, ${ }^{1}$ \\ Massimiliano Venusti, ${ }^{2}$ Daniela Sardo, ${ }^{2}$ \\ Daniele Casti, ${ }^{1}$ Francesca Cossu, ${ }^{1}$ \\ Sonia Lamon, ${ }^{1}$ Vincenzo Spanu, ${ }^{1}$ \\ Michela Ibba, ${ }^{1}$ Michela Marras, ${ }^{1}$ \\ Antonio Paba, ${ }^{3}$ Carlo Spanu, ${ }^{1}$ \\ Enrico Pietro Luigi De Santis ${ }^{1}$
}

'Department of Veterinary Medicine, University of Sassari, Sassari; ${ }^{2}$ LAORE Sardinia Agency, Zootechnical Production Department, Sassari; ${ }^{3}$ AGRIS Sardinia Agency, Department of Research on Animal Production, Sassari, Italy

\section{Abstract}

Ricotta fresca cheese is the product of Sardinian dairy industry most exposed to microbial post-process contamination. Due to its technological characteristics, intrinsic parameters, $\mathrm{pH}$ (6.10-6.80) and water activity (0.974-0.991), it represents an excellent substrate for the growth of spoilage and pathogenic microorganisms, which are usually resident in cheese-making plants environments. Generally, ricotta fresca has a shelf life of 5-7 days. For this reason, at industrial level, modified atmosphere packaging (MAP) is used to extend the durability of the product. However, few investigations have been conducted to validate the use of MAP in ricotta fresca. The aim of this work is to evaluate the shelf life of ricotta fresca under MAP. A total of 108 samples were collected from three Sardinian industrial cheese-making plants and analysed within 24 $\mathrm{h}$ after packaging and after 7, 14 and 21 days of refrigerated storage. Aerobic mesophilic bacteria, mesophilic and thermophilic cocci and lactobacilli, Enterobacteriaceae and E. coli, L. monocytogenes, Pseudomonas spp., Bacillus cereus, yeasts and moulds, and the chemicalphysical parameters and composition of the product were determined. At the end of the shelf life, Pseudomonas spp. and Enterobacteriaceae reached high concentrations, 5 to 7 and 3 to $6 \log _{10}$ colony forming unit $\mathrm{g}^{-1}$, respectively. The presence of environmental contaminants indicates that the use of MAP without the appropriate implementation of prerequisite programmes is not sufficient to extend the durability of ricotta fresca. Gas mixture and packaging material should be selected only on the basis of scientific evidence of their effectiveness.

\section{Introduction}

Ricotta fresca is a traditional cheese produced by heat coagulation of ovine whey. In order to enhance product texture and increase yield, ricotta fresca can be obtained from a blend of whey with milk or cream milk. In Sardinia it is typically produced from the whey remaining after the production of sheep's milk cheeses and it is also named ricotta fresca ovina or ricotta gentile (Ministerial Decree 8 September 1999, n.350; Italian Republic, 1999). In industrial cheese-making plants, the traditional batch process is applied. The whey is filtered, preheated to about $65^{\circ} \mathrm{C}$, sent to storage tanks and then to large open kettles, where, by steam injection or by indirect heating, the temperature rises to $80-82^{\circ} \mathrm{C}$. As the flocculated proteins start floating on the whey surface the heating is interrupted and the mixture is held for $15-20 \mathrm{~min}$. The clotted proteins are collected using perforated ladle and transferred into conic plastic baskets to drain. Ricotta baskets are then placed in cold rooms $\left(3 \pm 1^{\circ} \mathrm{C}\right)$ where they are allowed to drip and to rapidly cool down within $12 \mathrm{~h}$. The average weight of the final product is approximately 1.7 $\mathrm{kg}$, with $\mathrm{pH}$ ranging from 6.10 to 6.80 and water activity $\left(\mathrm{a}_{\mathrm{w}}\right)$ from 0.974 to 0.991 (De Santis et al., 1999). The mean composition is $70-80 \%$ moisture, $10-25 \%$ fat and $8-10 \%$ protein. Depending on the target market, ricotta can be wrapped in food paper or packaged in modified atmosphere packaging (MAP). Ricotta cheese wrapped in food paper is usually sold in proximity market, gourmet and specialty food stores, while the product in MAP in large-scale retailers. Ricotta fresca can be consumed as it is or as ingredient in sweet and savoury dishes. Durability defined by food business operators (FBO) of ricotta fresca differs depending on the packaging methods, being for the wrapped one 5-7 days while for ricotta in MAP up to 21 days. As a consequence of high temperatures applied during production, ricotta fresca cheese has naturally a poor competitive microflora (Pintado et al., 2002). At clotting it is mainly represented by bacterial spores survived at high temperatures, like Bacillus cereus spores (De Santis et al., 1999). The open nature of batch production, which includes handling of the curd after floating, exposes ricotta to secondary contamination originating from the equipment and the processing environment (Greenwood et al., 1991). An elevated risk of contamination exists in environments downstream curd flocculation such as moulding, chilling and packaging that are held in an environment not always equipped with adequate hygienic protection systems, like air filtration (Kousta et al., 2010). Sources of contamination are represented by food contact (i.e. drainage tables and
Correspondence: Carlo Spanu, Department of Veterinary Medicine, University of Sassari, via Vienna 2, 07100, Sassari, Italy.

Tel: +39.079.229454 - Fax: +39.079.229458.

E-mail: cspanu@uniss.it

Key words: Whey cheese; MAP; Ricotta cheese; Sheep milk.

Conflict of interest: the authors declare no potential conflict of interest.

Funding: this study was funded and promoted by the Agenzia LAORE Sardegna - Dipartimento per le produzioni zootecniche, Servizio produzioni zootecniche, Sassari, Italy.

Received for publication: 25 August 2015.

Revision received: 14 April 2016.

Accepted for publication: 14 April 2016.

This work is licensed under a Creative Commons Attribution-NonCommercial 4.0 International License (CC BY-NC 4.0).

(C) Copyright C. Pala et al., 2016

Licensee PAGEPress, Italy

Italian Journal of Food Safety 2016; 5:5502 doi:10.4081/ijfs.2016.5502

utensils) and non-food contact surfaces (i.e. floors, drains, outer parts of processing equipment). The contaminants can persist within niches in the processing environment protected by a structured biofilm ecosystem (Simões et al., 2009). From niches microorganism find their way into exposed food through direct contact, aerosol, dripping or water splashes and by means of operators. Even with the application of good hygiene practice (GHP) and good manufacturing practice (GMP), environmental contamination of ricotta cannot be avoided but only limited. Ricotta composition and its intrinsic properties, and the absence of preservatives in the formulation make this product an excellent substrate for the growth of spoilage and pathogen microorganisms (De Santis and Mazzette, 2002). The mean aerobic mesophilic bacteria counts $24 \mathrm{~h}$ after the production usually ranges between $<2.0$ and 3.0 $\log _{10}$ CFU g ${ }^{-1}$. During cold storage different groups of microorganisms such as coliforms, coagulase-negative staphylococci and psychotrophic $B$. cereus strains are able to grow even 1-2 $\log _{10}$ in $24 \mathrm{~h}$ (Pintado and Malcata, 2000). However, at refrigeration temperature psychotropic microorganisms belonging to the Pseudomonas genera can overgrow the other microflora and cause food spoilage (Champagne et al., 1994; Carrascosa et al., 2015). MAP is a packaging technique frequently used in the food industry in order to control the microbial growth (Peelman et al., 2014). After extraction of the air present in the headspace of the package, a mixture of $\mathrm{CO}_{2}, \mathrm{O}_{2}$ and 
$\mathrm{N}_{2}$ in different proportion is usually introduced before the packaging sealing. In order to have a good increase of the shelf life and maintain the desired $\mathrm{CO}_{2}$ concentration it is important to use a high-barrier packaging film and apply the vacuum as well as possible. MAP has been successfully used to extend the shelf life of a wide variety of ready-to-eat foods (GonzalezFandos et al., 2000). Several studies demonstrated the effectiveness of MAP in shelf life extension of hard and fresh cheeses (Eliot $e t$ al, 1998). Moir et al. (1993) demonstrated that MAP packaging can inhibit Pseudomonas spp. growth in soft cheese stored at 5 and $15^{\circ} \mathrm{C}$.

Due to the always-increasing demand by the large distribution of ricotta fresca with extended durability, in the last years Sardinian industrial cheese-making plants adopted MAP. The shelf life of MAP ricotta fresca is defined by the FBO and generally varies from 15 to 21 days. The use of MAP for the shelf life extension was previously evaluated in different ricotta cheeses from sheep (Del Nobile et al., 2009) or cow whey milk and in similar products such as Myzithra Kalathaki made in Greece (Dermiki et al., 2008). The aim of this work is to conduct a durability study to evaluate the evolution of the microbiological profile, physicochemical characteristics and composition of industrial sheep ricotta fresca cheese in MAP during refrigerated storage up to 21 days.

\section{Materials and Methods}

\section{Ricotta fresca cheese in modified atmosphere packaging samples}

The study was conducted in Sardinia (Italy) during the year 2014 enrolling three sheep milk industrial cheese-making plants (respectively A, B and C). The selected plants were representative of Sardinian sheep milk cheese-making production sector, characterised by similar ricotta manufacturing process and by the use of MAP. In each cheesemaking plant data about process, packaging technologies, and GMPs and GHPs enforcement level were collected. From each plant ricotta fresca cheese samples randomly selected from 3 different production batches, which were representative of the seasonal sheep's milk production (from November/December to July), were obtained. Therefore, samples were collected in February/March, April/May and June/July and identified as batch 1, 2 and 3, respectively. A total of 108 ricotta fresca samples were collected, 36 from each plant and 12 from each batch. All ricotta fresca samples were packaged the day after the production. The chosen gas mixtures were composed of $30 \% \mathrm{CO}_{2}$ and $70 \% \mathrm{~N}_{2}$ for two cheese-making plants (A, B) and $100 \% \mathrm{~N}_{2}$ for the third one (C) (Figure 1).

\section{Sampling plan}

Ricotta fresca cheese samples under refrigeration conditions $\left(3 \pm 1^{\circ} \mathrm{C}\right)$ were transported to the Department of Veterinary Medicine, University of Sassari, Sassari, and stored for laboratory analysis. Samples were analysed the day of the delivery $\left(\mathrm{T}_{0}\right)$, at $7\left(\mathrm{~T}_{7}\right), 14\left(\mathrm{~T}_{14}\right)$ and $21\left(\mathrm{~T}_{21}\right)$ days after the production for the determination of the headspaces gas concentration, composition, intrinsic properties, and microbiological analysis.

\section{Headspace gas composition}

Headspaces gas mixture composition was determined using the Dansensor gas analyser (PBI- Dansensor, Ringsted, Denmark). Determinations were conducted before all other analysis by piercing the surface of sealed ricotta fresca MAP samples with a sterile needle connected to the Dansensor. Measures of combined residual $\mathrm{O}_{2} \%$ and $\mathrm{CO}_{2} \%$ were directly read on the instrument, while $\mathrm{N}_{2}$ was obtained by difference.

\section{Microbiological analysis}

All microbiological analyses were conducted according to international standard methods and included the following parameters: total aerobic mesophilic counts (ISO 4833; ISO, 2003), Enterobacteriaceae (ISO 21528-2; ISO, 2004a), Listeria monocytogenes (ISO 112901/2; ISO, 1996, 1998), Pseudomonas spp. (ISO/TS 11059:2009; ISO, 2009), B. cereus (ISO 7932; ISO, 2004b), yeast and moulds (ISO 6611/IDF 94; ISO, 2004c). Presumptive mesophilic and thermophilic cocci were enumerated on M17 agar (Microbiol, Cagliari, Italy) incubated anaerobically for $72 \mathrm{~h}$ at $30^{\circ} \mathrm{C}$ and at $45^{\circ} \mathrm{C}$, respectively. Presumptive mesophilic lactobacilli were enumerated on $\mathrm{FH}$ agar (Isolini et al. 1990) and anaerobically incubated at $37^{\circ} \mathrm{C}$ for $72 \mathrm{~h}$. Presumptive thermophilic lactobacilli were enumerated on MRS agar (Microbiol) adjusted to $\mathrm{pH}$ 5.4, anaerobically incubated at $45^{\circ} \mathrm{C}$ for $72 \mathrm{~h}$. The KAA agar medium (Lab M Limited, Heywood, UK), aerobically incubated at $42^{\circ} \mathrm{C}$ for $18 \mathrm{~h}$, was used for presumptive enterococci enumeration. From each samples two $25 \mathrm{~g}$ aliquots were aseptically collected and homogenised, one with $225 \mathrm{~mL}$ of fraser broth base (Biolife, Milan, Italy) for the detection of $L$. monocytogenes and one with $225 \mathrm{~mL}$ of buffered pepton water (BPW) (Biolife) for all other parameters. After homogenisation, serial decimal dilutions were prepared in BPW solution and inoculated onto agar plates containing the culture media appropriate for each of the parameter to be investigated.

\section{Physico-chemical analysis and composition}

From each ricotta fresca cheese sample $40 \mathrm{~g}$, representative of the whole products, were sampled. Intrinsic properties ( $\mathrm{pH}$ and $\mathrm{a}_{\mathrm{w}}$ ) were measured using $\mathrm{pH}$ meter GLP22 (Crison Instruments, Barcelona, Spain) and $\mathrm{a}_{\mathrm{w}}$-meter Aqualab 4TE (Decagon, Pullman, WA, USA), respectively. Fat, moisture, protein were analysed using a near infrared transmittance compositional analyser (FOSS, Eden Prairie, MN, USA).

\section{Statistical analysis}

Differences among average microbiological counts [ colony forming unit (CFU) $\mathrm{g}^{-1}$ ], headspace gas concentration (\%), intrinsic proper-

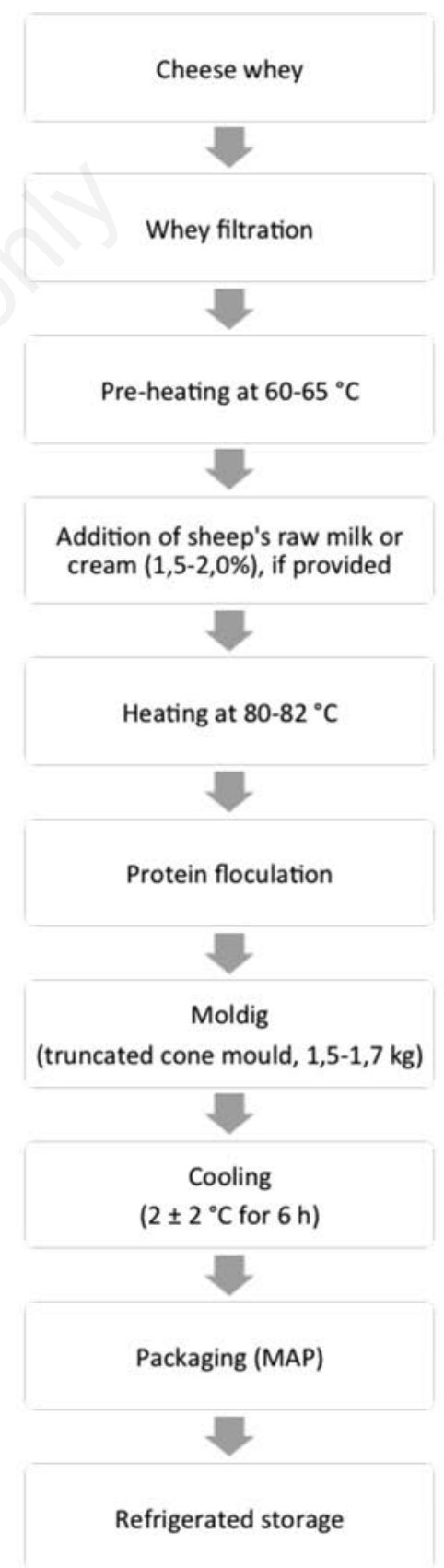

Figure 1. Process flow diagram of modified atmosphere packaged ricotta fresca. 
ties (x) and centesimal composition (\%) over time $\left(\mathrm{T}_{0}, \mathrm{~T}_{7}, \mathrm{~T}_{14}\right.$ and $\left.\mathrm{T}_{21}\right)$ were compared using Fisher's least significant difference test. Statistical analyses were performed with Statgraphics Centurion XVI software (Stat Point Technologies, Warrenton, VA, USA).

\section{Results}

\section{Headspace gas composition}

The headspace gas composition values for each cheese-making plant at each sampling time are reported in Table 1. The gas mixtures composition used in ricotta fresca cheese packaging lines was $30 \% \mathrm{CO}_{2}$ and $70 \% \mathrm{~N}_{2}$ for two cheese-making plants (A and B) and 100\% $\mathrm{N}_{2}$ for the third one (C). In samples from $A$ and $B$ plants the $\mathrm{CO}_{2} \%$ at $\mathrm{T}_{0}$ was $10.96 \pm 0.93$ and $8.50 \pm 2.92$ respectively, i.e. values three times lower than in the gas mixtures. A further considerable $\mathrm{CO}_{2} \%$ decrease was detected at $\mathrm{T}_{7}$, when it reached values as low as $3.38 \pm 1.85$ (A) and $4.11 \pm 1.85$ (B). More differences were detected in $\mathrm{CO}_{2} \%$ between products from $\mathrm{A}$ and $\mathrm{B}$ cheese-making plants at $\mathrm{T}_{14}$ and $\mathrm{T}_{21}$ during refrigerated storage. The $0_{2} \%$ ranged between $1.38 \pm 2.52 \%$ (C) and $4.48 \pm 3.0$ (B) at $\mathrm{T}_{0}$. The $\mathrm{O}_{2} \%$ shows a progressive reduction until $\mathrm{T}_{21}$. In samples from cheese-making plant $\mathrm{C}$, where only $\mathrm{N}_{2}$ was used as gas for MAP, slight decrease was observed in $\mathrm{N}_{2} \%$, the $\mathrm{O}_{2}$ residual $\%$ detected at $\mathrm{T}_{0}$ showed a decrease during storage, while $\mathrm{CO}_{2}$ that was not detected at $\mathrm{T}_{0}$ increased until $1.87 \pm 1.43 \%$ at $\mathrm{T}_{21}$.

\section{Physico-chemical parameters and composition}

Slight $\mathrm{pH}$ differences at $\mathrm{T}_{0}$ were observed in samples from cheese-making plants (6.476.65) with very low variations after storage at $\mathrm{T}_{21}$ (6.50-6.62). $\mathrm{A}_{\mathrm{w}}$ levels were usually $>0.990$ with very low variations among samples and storage times. Composition values (mean \pm standard deviation) in all samples were: protein $8.48 \pm 0.66 \%$, fat $11.94 \% \pm 2.37$, and moisture $76.36 \pm 2.44$. Higher fat content in samples from cheese-making plant B $(\mathrm{P}<0.001)$ was detected in other samples due to cream addition. Table 2 reports the evolution of $\mathrm{pH}$ and $\mathrm{a}_{\mathrm{w}}$, while Table 3 the evolution of chemical parameters during shelf life.

\section{Microbiological profile}

The aerobic mesophilic bacteria count at $\mathrm{T}_{0}$ in the samples where it was detectable (positive sample) was between 2.4-2.7 $\log _{10} \mathrm{CFU} \mathrm{g}^{-1}$, while higher variability was shown by the positive rate ranging from 44.4 to $100 \%$ depending on cheese-making plants (Table 4). During storage, counts progressively increased $(\mathrm{P}<0.001)$ reaching levels $>7 \log _{10} \mathrm{CFU} \mathrm{g}{ }^{-1}$ at $\mathrm{T}_{14}$ and $\mathrm{T}_{21}$ in samples from $\mathrm{B}$ and $\mathrm{C}$ dairies, while in samples from A plant they were about $6 \log _{10} \mathrm{CFU} \mathrm{g}^{-1}(\mathrm{P}<0.001)$ and were detected only at $\mathrm{T}_{21}$. Enterobacteriaceae were detectable only in a sample in dairy $\mathrm{B}$ at $\mathrm{T}_{0}$ and during the whole shelf life period (from $\mathrm{T}_{7}$ to $\mathrm{T}_{21}$ ) in sam-

Table 1. Evolution of $\mathrm{O}_{2}, \mathrm{CO}_{2}$ and $\mathrm{N}_{2}$ percentage (mean \pm standard deviation) in the headspace of ricotta fresca cheese manufactured in three cheese-making plants (three different batches).

\begin{tabular}{|c|c|c|c|c|c|c|c|c|c|c|c|c|}
\hline \multirow{2}{*}{ Plant } & \multicolumn{4}{|c|}{$\mathrm{O}_{2}$} & \multicolumn{4}{|c|}{$\mathrm{CO}_{2}$} & \multicolumn{4}{|c|}{$\mathrm{N}_{2}$} \\
\hline & $\mathrm{T}_{0}$ & $\mathrm{~T}_{7}$ & $\mathrm{~T}_{14}$ & $T_{21}$ & $\mathrm{~T}_{0}$ & $\mathrm{~T}_{7}$ & $\mathrm{~T}_{14}$ & $\mathrm{~T}_{21}$ & $\mathrm{~T}_{0}$ & $\mathrm{~T}_{7}$ & $\mathrm{~T}_{14}$ & $\mathrm{~T}_{21}$ \\
\hline A & $1.69 \pm 0.94^{\mathrm{a}}$ & $3.08 \pm 1.41^{\mathrm{ab}}$ & $3.82 \pm 2.54^{b}$ & $2.10 \pm 0.39^{\mathrm{a}}$ & $10.96 \pm 0.93^{\mathrm{a}}$ & $3.38 \pm 1.85^{b}$ & $3.00 \pm 1.18^{b}$ & $3.18 \pm 1.11^{\mathrm{b}}$ & $87.35 \pm 1.02^{\mathrm{a}}$ & $93.55 \pm 1.29 \mathrm{bc}$ & $93.18 \pm 2.12^{\mathrm{b}}$ & $94.72 \pm 0.96^{c}$ \\
\hline B & $4.48 \pm 3.00^{\mathrm{a}}$ & $5.08 \pm 2.97^{\mathrm{a}}$ & $1.25 \pm 1.46^{\mathrm{b}}$ & $0.0 \pm 0.0^{\mathrm{b}}$ & $8.50 \pm 2.92^{\mathrm{a}}$ & $4.11 \pm 1.85^{b}$ & $5.99 \pm 2.47^{\mathrm{ab}}$ & $8.12 \pm 3.49 \mathrm{a}$ & $87.02 \pm 2.58^{a}$ & $90.81 \pm 2.70^{\mathrm{b}}$ & $92.76 \pm 2.10^{b}$ & $91.88 \pm 3.59^{\mathrm{b}}$ \\
\hline C & $1.38 \pm 05^{\mathrm{a}}$ & $1.57 \pm 0.24^{\mathrm{a}}$ & $0.02 \pm 0.03^{b}$ & $0.04 \pm 0.12^{b}$ & $0.00 \pm 0.00^{\mathrm{a}}$ & $0.18 \pm 0.27$ & $0.59 \pm 0.55^{\mathrm{a}}$ & $1.87 \pm 1.45^{b}$ & $98.62 \pm 0.57^{\mathrm{ab}}$ & $98.25 \pm 0.22^{\mathrm{a}}$ & $99.39 \pm 0.55^{b}$ & $98.09 \pm 1.40^{\mathrm{a}}$ \\
\hline
\end{tabular}

The sampling times $\mathrm{T}_{0} \mathrm{~T}_{7}, \mathrm{~T}_{14}$ and $\mathrm{T}_{21}$ refer to the days $\left(0,7,14\right.$, and 21 , respectively) elapsed during the shelf life. ${ }^{\mathrm{a}-\mathrm{C}} \mathrm{Means}$ in the same row with different superscript letters are significantly different ( $\mathrm{P}<0.05$ ).

Table 2. Evolution of $\mathrm{pH}$ and water activity (mean of three batches \pm standard deviation) of ricotta fresca manufactured in three cheesemaking plants during shelf life.

\begin{tabular}{lcccccccc} 
Plant & \multicolumn{2}{c}{$\mathrm{pH}$} & & & $\mathrm{a}_{\mathrm{w}}$ & $\mathrm{T}_{14}$ & $\mathrm{~T}_{21}$ \\
$\mathrm{~A}$ & $\mathrm{~T}_{0}$ & $\mathrm{~T}_{7}$ & $\mathrm{~T}_{14}$ & $\mathrm{~T}_{21}$ & $\mathrm{~T}_{7}$ & & & \\
$\mathrm{~A}$ & $6.47 \pm 0.08^{\mathrm{a}}$ & $6.46 \pm 0.15^{\mathrm{a}}$ & $6.57 \pm 0.11^{\mathrm{a}}$ & $6.50 \pm 0.07^{\mathrm{a}}$ & $0.994 \pm 0.002^{\mathrm{a}}$ & $0.993 \pm 0.003^{\mathrm{ab}}$ & $0.990 \pm 0.005^{\mathrm{bc}}$ & $0.989 \pm 0.005^{\mathrm{c}}$ \\
$\mathrm{B}$ & $6.74 \pm 0.31^{\mathrm{a}}$ & $6.73 \pm 0.09^{\mathrm{a}}$ & $6.62 \pm 0.32^{\mathrm{bc}}$ & $6.53 \pm 0.26^{\mathrm{b}}$ & $0.989 \pm 0.003^{\mathrm{a}}$ & $0.991 \pm 0.005^{\mathrm{a}}$ & $0.989 \pm 0.011^{\mathrm{a}}$ & $0.989 \pm 0.011^{\mathrm{a}}$ \\
\hline $\mathrm{C}$ & $6.65 \pm 0.14^{\mathrm{a}}$ & $6.71 \pm 0.06^{\mathrm{ab}}$ & $6.82 \pm 0.09^{\mathrm{b}}$ & $6.62 \pm 0.25^{\mathrm{a}}$ & $0.992 \pm 0.003^{\mathrm{a}}$ & $0.993 \pm 0.002^{\mathrm{a}}$ & $0.990 \pm 0.006^{\mathrm{a}}$ & $0.991 \pm 0.006^{\mathrm{a}}$ \\
\hline
\end{tabular}

$\mathrm{a}_{\mathrm{w}}$, water activity. The sampling times $\mathrm{T}_{0,} \mathrm{~T}_{7}, \mathrm{~T}_{14}$ and $\mathrm{T}_{21}$ refer to the days $\left(0,7,14\right.$, and 21 , respectively) elapsed during shelf life. ${ }^{-a}$ Means in the same row with different superscript letters are significantly different $(\mathrm{P}<0.05)$.

Table 3. Evolution of ricotta fresca cheese composition (mean \pm standard deviation) from three batches produced in three cheese-making plants during shelf life.

\begin{tabular}{lccccc} 
Composition & Plant & $\mathrm{T}_{0}$ & $\mathrm{~T}_{7}$ & $\mathrm{~T}_{14}$ & $\mathrm{~T}_{21}$ \\
Moisture & $\mathrm{A}$ & $78.49 \pm 1.76$ & $76.81 \pm 1.96$ & $76.68 \pm 1.71$ & $76.69 \pm 2.63$ \\
& $\mathrm{~B}$ & $72.88 \pm 3.17$ & $73.26 \pm 3.47$ & $72.15 \pm 4.33$ & $73.00 \pm 1.86$ \\
\hline \multirow{2}{*}{ Fat } & $\mathrm{C}$ & $79.22 \pm 2.43$ & $78.14 \pm 1.54$ & $78.99 \pm 1.51$ & $80.03 \pm 2.92$ \\
\hline \multirow{2}{*}{ Protein } & $\mathrm{A}$ & $9.82 \pm 1.59$ & $11.13 \pm 1.69$ & $10.50 \pm 2.25$ & $11.44 \pm 2.82$ \\
\hline & $\mathrm{B}$ & $15.29 \pm 3.63$ & $15.22 \pm 1.69$ & $16.11 \pm 4.83$ & $15.82 \pm 2.15$ \\
\hline & $\mathrm{C}$ & $8.96 \pm 1.31$ & $10.11 \pm 1.90$ & $9.89 \pm 1.92$ & $9.01 \pm 2.60$ \\
\hline
\end{tabular}

The sampling times $T_{0,} T_{7}, T_{14}$ and $T_{21}$ refer to the days $(0,7,14$, and 21 , respectively) elapsed during shelf life. 
ples from cheese-making plants B and C, reaching $6.10 \pm 0.81$ (B) and $5.83 \pm 1.55$ (C) $\log _{10} \mathrm{CFU} \mathrm{g}^{-1}\left(\mathrm{~T}_{21}\right)$. Enterobacteriaceae contamination levels in samples from A plant were lower than in $\mathrm{B}$ and $\mathrm{C}$ and those microorganisms were detected only at $\mathrm{T}_{21}$ (2 out 9 samples) when they reached $3.46 \pm 1.32 \log _{10} \mathrm{CFU} \mathrm{g}^{-1}$ (Table 4).

Pseudomonas spp. was detectable at $\mathrm{T}_{0}$ only in samples from cheese-making plant $\mathrm{B}$, while it was always recovered in all samples from $T_{7}$ onwards. In samples collected from B and C cheese-making plants similar levels of Pseudomonas spp. were found with a significant increase from $\mathrm{T}_{7}$ to $\mathrm{T}_{14}$ where maximum values of $7.43 \pm 0.67$ and $7.26 \pm 0.69 \log _{10} \mathrm{CFU} \mathrm{g}^{-1}$ were reached. The concentration of Pseudomonas spp. in dairy A samples was lower $(\mathrm{P}<0.001)$ than $\mathrm{B}$ and $\mathrm{C}$, and it reached values of $5.99 \pm 1.24 \log _{10}$ CFU g ${ }^{-1}$ at $\mathrm{T}_{21}$ (Table 4). Mesophilic and thermophilic lactobacilli were never detected. Mesophilic cocci were found in 67 out 108 (62.0\%) samples with a prevalence of $54.0 \%$ (A), $87.5 \%$ (B) and $41.6 \%$ (C). The mesophilic cocci counts increased during the shelf life in all samples from $0.99 \pm 1.31 \log _{10}$ CFU g ${ }^{-1}$ at $\mathrm{T}_{0}$ to $3.33 \pm 2.74 \log _{10} \mathrm{CFU} \mathrm{g}^{-1}$ at $\mathrm{T}_{21}$. Thermophilic cocci were detected in $27 \mathrm{sam}$ ples (25\%) with levels of $2.79 \pm 0.90$. Enterococci were detected in 5 samples (4.63\%) collected from B and C plants with concentration of $3.32 \pm 1.04 \log _{10} \mathrm{CFU} \mathrm{g}^{-1}$. In all samples $L$. monocytogenes, $E$. coli and $B$. cereus were always below the detection limit.

\section{Discussion}

MAP has been widely used to extend the shelf life of several ready-to-eat foods including dairy products. Literature reports several studies validating the use of MAP packaging in ricotta cheese, hard and soft cheeses such as mozzarella, stracciatella, fior di latte, cottage and myzithra kalathaki with various gases mixture (Moir et al., 1993; Eliot et al., 1998; Dermiki et al., 2008; Conte et al., 2011; Del Nobile et al., 2009; Gammariello et al., 2009; Mastromatteo et al., 2014). The increasing demand of ricotta fresca cheese by large-scale retail with extended durability drives the use of MAP or of alternative production technologies, like the packaging of hot homogenized products (De Santis et al., 1999). MAP industrial ricotta fresca produced in Sardinia has already been on the market for several years, with a shelf life extended by FBO until 21 days. However, no scientific evidence supports the definition of this durability. The first evidence obtained with the survey is that differences exist in the initial gas composition used by different operators. Two cheese-making plants used a mixture of $30 \% \mathrm{CO}_{2}$ and $70 \% \mathrm{~N}_{2}(\mathrm{~A}, \mathrm{~B})$, while the third cheese-making plant used only $\mathrm{N}_{2}$ (C). No justification on the use of a mixture is given by FBO. Another observation is that even with similar gas injection the actual initial composition in the headspace is different and changes over time. Samples from cheesemaking plants $\mathrm{A}$ and $\mathrm{B}$ at $\mathrm{T}_{0}$ showed a different $\mathrm{CO}_{2}$ levels variability $(\mathrm{B}>\mathrm{A})$ as a result of different packaging procedures. In plant $B$ insufficient headspace was left and inaccuracy of gas injection occurred. $\mathrm{At}_{0} \mathrm{CO}_{2}$ concentration in headspace differs from level provided in the gas mixture as a result of prompt gas solving on the product. The further $\mathrm{CO}_{2}$ reductions after the first storage week could be related to packaging permeability, as confirmed by evidence collected during visits at cheese-making plants showing non-compliance of packaging materials with the requirement of high density barrier (the $\mathrm{O}_{2}$ transfer rate at $20^{\circ} \mathrm{C}$ and $65 \%$ RH was about $30 \mathrm{cc} / \mathrm{m}^{2}$ ). In samples where poor microbiological characteristics were observed at $\mathrm{T}_{14}$ and $\mathrm{T}_{21}$ (dairy $\mathrm{B}$ ) a further increase in $\mathrm{CO}_{2}$ is associated with high aerobic mesophilic bacteria level (>log $7 \mathrm{CFU} \mathrm{g}^{-1}$ ) resulting in $\mathrm{CO}_{2}$ release in the headspace, as a microbial fermentation product. The same evolution could be observed in samples from dairy
$\mathrm{C}$ with a slight $\mathrm{CO}_{2}$ increase in the last part of storage. The $0_{2} \%$ at $\mathrm{T}_{0}$ was higher than $1 \%$, and in dairy B lacking in control of residual level of this gas as showed by concentration $>4 \%$. The $\mathrm{O}_{2}$ reduction during storage is associated with the increase of aerobic mesophilic microbial count. The changes in the relative concentrations of $\mathrm{CO}_{2}$ and $\mathrm{O}_{2}$ during storage resulted in higher variability of $\mathrm{N}_{2}$ levels, obviously lower in product from dairy $\mathrm{C}$, where it was the only component of the initial gas mixture. The residual $\mathrm{O}_{2}$ combined with intrinsic properties and absence of competitive microflora makes ricotta fresca an excellent substrate for growth of aerobic psychrotrophic spoilage and pathogen microorganism. In analysed samples pathogens like $L$. monocytogenes and $B$. cereus were never detected, while spoilage psychrotrophic microorganism such as Pseudomonas spp. can overgrow other microflora reducing the risk of pathogens growth (Buchanan and Bagi, 1999). Furthermore, the combination of low temperatures and long storage time represents a selective advantage for Pseudomonas spp. (Carrascosa et al., 2015). Pseudomonas spp. as high as $7 \log$ CFU g ${ }^{-1}$ in ricotta cheese should be regarded as values reached in spoiled products. High concentration of Pseudomonas spp. negatively affects the flavour and the texture of the product (Leriche et al., 2004). An important feature of some Pseudomonas spp. is the secretion of the yellow-green pyoverdin (Meyer et al., 2002) or blue pyocyanin (Cantoni et al., 2003) that induce important discoloration of the product. Microbial levels in ricotta fresca cheese at production occurred mostly as a post-process contamination, depending from GMP and GHP enforcement at production and packaging. During the preliminary inspection in cheese-making plants $B$ and $\mathrm{C}$, evidence of poor implementation of hygiene management (e.g., sanification, personnel hygiene and training, etc.), process control and packaging procedures were observed. Failure in hygienic management resulted in higher

Table 4. Microbiological profile $\left(\log _{10}\right.$ colony forming unit $\mathrm{g}^{-1}$; mean of three batches \pm standard deviation (ricotta fresca) of $\mathrm{I}$ manufactured in three different cheese-making plants during shelf life.

\begin{tabular}{|c|c|c|c|c|c|}
\hline Parameters & Plants & $\mathrm{T}_{0}$ & $\mathrm{~T}_{7}$ & $\mathrm{~T}_{14}$ & $\mathrm{~T}_{21}$ \\
\hline Aerobic mesophilic bacteria & $\begin{array}{l}\text { A } \\
\text { B } \\
\text { C }\end{array}$ & $\begin{array}{l}2.43 \pm 0.21^{\mathrm{a}}(4 / 9) \\
3.56 \pm 0.69^{\mathrm{a}}(8 / 9) \\
2.70 \pm 0.38^{\mathrm{a}}(9 / 9)\end{array}$ & $\begin{array}{l}2.41 \pm 0.48^{\mathrm{a}}(6 / 9) \\
5.51 \pm 1.38^{\mathrm{b}}(9 / 9) \\
4.16 \pm 1.81^{\mathrm{b}}(9 / 9)\end{array}$ & $\begin{array}{l}4.70 \pm 1.18^{\mathrm{b}}(8 / 9) \\
7.22 \pm 0.45^{\mathrm{c}}(9 / 9) \\
6.91 \pm 0.89^{\mathrm{c}}(9 / 9)\end{array}$ & $\begin{array}{l}5.91 \pm 1.14^{c}(9 / 9) \\
7.09 \pm 0.75^{c}(9 / 9) \\
7.43 \pm 0.50^{c}(9 / 9)\end{array}$ \\
\hline Enterobacteriaceae & $\begin{array}{l}\text { A } \\
\text { B } \\
\text { C }\end{array}$ & $\begin{array}{c}\text { nda }(0 / 9) \\
3.09 \pm 0.00^{\mathrm{a}}(1 / 9) \\
\text { nd }^{\mathrm{a}}(0 / 9)\end{array}$ & $\begin{array}{c}\text { nda }(0 / 9) \\
3.53 \pm 1.48^{\mathrm{a}}(7 / 9) \\
2.66 \pm 0.94^{\mathrm{b}}(6 / 9)\end{array}$ & $\begin{array}{c}\mathrm{nd}^{\mathrm{a}}(0 / 9) \\
5.07 \pm 1.11^{\mathrm{b}}(9 / 9) \\
5.06 \pm 1.03^{\mathrm{c}}(9 / 9)\end{array}$ & $\begin{array}{l}3.46 \pm 1.32^{\mathrm{b}}(2 / 9) \\
6.10 \pm 0.81^{\mathrm{c}}(9 / 9) \\
5.83 \pm 1.55^{\mathrm{c}}(9 / 9)\end{array}$ \\
\hline Pseudomonas spp. & $\begin{array}{l}\text { A } \\
\text { B } \\
\text { C }\end{array}$ & $\begin{array}{c}\mathrm{nd}^{\mathrm{a}}(0 / 9) \\
3.41 \pm 0.71^{\mathrm{a}}(3 / 9) \\
\mathrm{nd}^{\mathrm{a}}(0 / 9)\end{array}$ & $\begin{array}{l}3.08 \pm 0.18^{\mathrm{b}}(2 / 9) \\
5.47 \pm 1.43^{\mathrm{b}}(9 / 9) \\
5.92 \pm 0.80^{\mathrm{b}}(9 / 9)\end{array}$ & $\begin{array}{l}5.06 \pm 1.15^{c}(6 / 9) \\
7.26 \pm 0.69^{c}(9 / 9) \\
7.43 \pm 0.67^{c}(9 / 9)\end{array}$ & $\begin{array}{l}5.99 \pm 1.24^{c}(6 / 9) \\
7.21 \pm 0.43^{c}(9 / 9) \\
7.28 \pm 1.05^{c}(9 / 9)\end{array}$ \\
\hline
\end{tabular}

nd, not detectable (below the detection limit). The sampling times $\mathrm{T}_{0}, \mathrm{~T}_{7}, \mathrm{~T}_{14}$ and $\mathrm{T}_{21}$ refer to the days $(0,7,14$, and 21 , respectively) elapsed during shelf life. The number of positive samples is within brackets. acc Means in the same row with different superscript letters are significantly different $(\mathrm{P}<0.05)$. 
contamination levels of ricotta cheese at $\mathrm{T}_{0,}$ in a faster increase of microorganisms since 4-5 $\log$ at $\mathrm{T}_{7}$, and high level of aerobic mesophilic counts, Pseudomonas spp. and Enterobacteriaceae at $\mathrm{T}_{14}$. Efficacy of MAP is conditioned by several factors, like the relationship between the product volume and the headspace, the residual $\mathrm{O}_{2}$ rate contained in the product, the level of vacuum and the correct selection of packaging materials (Khoshgozaran et al., 2012). MAP needs specific shelf life studies with controlled experimental parameters in order to assess the efficacy in controlling spoilage and pathogen microorganisms and to define the durability of ricotta fresca based on scientific evidences.

\section{Conclusions}

Considering the microbial evolution and high prevalence of contaminants, particularly in Pseudomonas spp., in two of three dairies, it is reasonable to assume that results confirmed the different good hygiene and manufacturing practices levels evaluated during the preliminary visits in each dairy plant. Despite MAP packaging, the ricotta fresca shelf life is significantly influenced by GMP and GHP applied during production, packaging and storage. Furthermore, the extended durability of chilled products, especially with little or no presence of competitive microflora, exposes the product to the growth of spoilage and pathogen microorganisms. There is no evidence that the actual MAP conditions used in Sardinian cheese-making plants allow to extend the ricotta fresca shelf life to 21 days.

\section{References}

Buchanan RL, Bagi K, 1999. Microbial competition: effect of Pseudomonas fluorescens on the growth of Listeria monocytogenes. Food Microbiol 16:523-9.

Cantoni C, Stella S, Cozzi M, Iacumin L, Comi G, 2003. Blue colouring in mozzarella cheese. Ind Aliment 42:840-3.

Champagne CP, Laing RR, Roy D, Mafu AA, 1994. Psycrotrophs in dairy products: their effects and their control. Food Sci Nutr 34:1-30.

Conte A, Brescia I, Del Nobile MA, 2011. Lysozyme/EDTA disodium salt and modified-atmosphere packaging to prolong the shelf life of burrata cheese. J Dairy Sci 94:5289-97.

Corrascosa C, Millána R, Jaberb JR, Lupiolac P, Del Rosario-Quintanad C, Mauricioa C, Sanjuán E, 2015. Blue pigment in fresh cheese produced by Pseudomonas fluo- rescens. Food Control 54:95-102.

Del Nobile MA, Conte A, Incoronato AL, Panza 0, 2009. Modified atmosphere packaging to improve the microbial stability of ricotta. African J Microbiol Res 3:137-42.

De Santis EPL, Mazzette R, 2002. La ricotta un substrato ideale. Caseus 7:42-4.

De Santis EPL, Mazzette R, Scintu MF, Deriu A, Carta A, 1999. Prove di produzione industriale della ricotta ovina confezionata: evoluzione dei parametri microbiologici nel corso della conservazione. A.I.V.I. 1999:183-8.

Dermiki M, Ntzimani A, Badeka A, Savvaidis IN, Kontominas MG, 2008. Shelf life extension and quality attributes of the whey cheese "Myzithra Kalathaki" using modified atmosphere packaging. Food Sci Technol 41:284-94.

Eliot SC, Vuillemard JC, Edmond JP, 1998. Stability of shredded mozzarella cheese under modified atmospheres. J Food Sci 63:1027-80.

Gammariello DA, Di Giulio S, Attanasio M, Del Nobile MA, 2009. Shelf life of Stracciatella cheese under modified-atmosphere packaging. J Dairy Sci 92:483-90.

Gonzalez-Fandos E, Sanz S, Olarte C, 2000. Microbiological, physicochemical and sensory characteristics of Cameros cheese packaged under modified atmospheres. Food Microbiol 17:407-14.

Greenwood MH, Roberts D, Burden P, 1991. The occurrence of Listeria species in milk and dairy products: a national survey in England and Wales. Int J Food Microbiol 12:197-206.

Isolini D, Grand M, Glattli H, 1990. Selektivmedien zum Nachweis von obligat und fakultativ heterofermentative Laktobazillen. Schweiz Milchwirtsch Forsch 19:57-9.

ISO, 1996. Microbiology of food and animal feeding stuffs-horizontal method for the detection and enumeration of Listeria monocytogenes. Part 1: detection method. ISO Norm 11290-1:1996. International Standardization Organization ed., Geneva, Switzerland.

ISO, 1998. Microbiology of food and animal feeding stuffs-horizontal method for the detection and enumeration of Listeria monocytogenes. Part 2: enumeration method. ISO Norm 11290-2:1998. International Standardization Organization ed., Geneva, Switzerland.

ISO, 2003. Microbiology of food and animal feeding stuffs. Horizontal method for the enumeration of microorganisms: colony count technique at $30^{\circ} \mathrm{C}$. ISO Norm 4833:2003. International Standardization Organization ed., Geneva, Switzerland.

ISO, 2004a. Microbiology of food and animal feeding stuffs. Horizontal method for the detection and enumeration of Enterobacteriaceae. Part 1: detection and enumeration by colony count technique. IS0 Norm 21528-2:2004. International Standardization Organization ed., Geneva, Switzerland.

ISO, 2004b. Microbiology of food and animal feeding stuffs. Horizontal method for the enumeration of presumptive Bacillus cereus and colony-count technique at $30^{\circ} \mathrm{C}$. ISO Norm 7932:2004. International Standardization Organization ed., Geneva, Switzerland.

ISO, 2004c. Milk and milk products. Enumetaration of colony forming units of yeast and moulds. Colony count technique at $25^{\circ} \mathrm{C}$. ISO Norm 6611. International Standardization Organization ed., Geneva, Switzerland.

ISO, 2009. Milk and milk products. Method for the enumeration of Pseudomonas spp. ISO/TS Norm 11059:2009 (IDF/RM 225:2009). International Standardization Organization ed., Geneva, Switzerland.

Italian Republic, 1999. Ministerial Decrere 8 September 1999, n.350. [Regolamento recante norme per l'individuazione dei prodotti tradizionali di cui all'articolo 8, comma 1, del decreto legislativo 30 aprile 1998, n. 173]. [Regulation in Italian]. In: Official Journal, 12 October 1999 n. 240.

Khoshgozaran S, Azizi MH, Bagheripoor Fallah $\mathrm{N}, 2012$. Evaluating the effect of modified atmosphere packaging on cheese characteristics: a review. Dairy Sci Technol 92:124.

Kousta M, Mataragas M, Skandamis P, Drosinos EH, 2010. Prevalence and sources of cheese contamination with pathogens at farm and processing levels. Food Control 21:805-15.

Leriche F, Bordessoulesb A, Fayollea K, Karoui R, Lavalb K, Leblanca L, Dufour E, 2004. Alteration of raw-milk cheese by Pseudomonas spp.: monitoring the sources of contamination using fluorescence spectroscopy and metabolic profiling. J Microbiol Meth 59:33-41.

Mastromatteo M, Conte A, Faccia M, Del Nobile MA, Zambrini V, 2014. Combined effect of active coating and modified atmosphere packaging on prolonging the shelf life of low-moisture Mozzarella cheese. J Dairy Sci 97:36-45.

Meyer JM, Geoffroy VA, Baida N, Gardan L, Izard D, Lemanceau P, 2002. Siderophore typing, a powerful tool for the identification of fluorescent and non fluorescent pseudomonads. Appl Environ Microb 68:2745-53.

Moir CJ, Eyles MJ, Davey JA, 1993. Inhibition of Pseudomonas in cottage cheese by packaging in atmospheres containing carbon dioxide. Food Microbiol 10:345-51. 
Peelman N, Ragaert P, Vandemoortele A, Verguldt E, De Meulenaer B, Devlieghere F, 2014. Use of biobased materials for modified atmosphere packaging of short and medium shelf life food products. Innov Food Sci Emerg Technol 26:319-29.

Pintado ME, Macedo AC, Malcata FX, 2002. Review: technology, chemistry and micro- biology of whey cheeses. Escola Superior de Biotecnologia, Universidade Católica Portuguesa ed., Porto, Portugal.

Pintado ME, Malcata FX, 1999. The effect of modified atmosphere packaging on the microbial ecology in Requezjao, a Portuguese whey cheese. J Food Process Pres 24:107-24.
Pintado ME, Malcata FX, 2000 Characterization of whey cheese packaged under vacuum. J Food Process Pres $63: 216-21$.

Simões M, Simões LC, Vieira MJ, 2009. Species association increases biofilm resistance to chemical and mechanical treatments. Water Res 43:229-37. 